\title{
SCCOHT tumors acquire chemoresistance and protection by interacting mesenchymal stroma/stem cells within the tumor microenvironment
}

\author{
ANNA OTTE ${ }^{1}$, YUANYUAN YANG ${ }^{1,3}$, JULIANE VON DER OHE ${ }^{1}$, CATHARINA MELZER $^{1}$, \\ PETER HILLEMANNS ${ }^{1}$, FRIEDRICH FEUERHAKE ${ }^{2}$ and RALF HASS ${ }^{1}$ \\ ${ }^{1}$ Biochemistry and Tumor Biology Lab, Department of Obstetrics and Gynecology and \\ ${ }^{2}$ Institute for Pathology, Hannover Medical School, D-30625 Hannover, Germany; \\ ${ }^{3}$ Tongji Hospital Affiliated Tongji University, Shanghai 200065, P.R. China
}

Received August 10, 2016; Accepted September 19, 2016

DOI: $10.3892 /$ ijo.2016.3735

\begin{abstract}
Chemotherapeutic drug testing of SCCOHT-1 and BIN-67 tumor cells revealed synergistic growth-inhibition of $>95 \%$ in vitro with a combination of foretinib and FK228. Application of this drug combination in vivo in NODscid miceinduced SCCOHT-1 ${ }^{\mathrm{GFP}}$ tumors was associated with $\sim 6$-fold reduction in tumor mass within 10 days, whereby synergistic effects of the two compounds remained undetectable compared to previous results with foretinib treatment alone. Histopathologic evaluation revealed a reduced vascularization and a lower amount of proliferating cells in the treated tumors. Surprisingly, a simultaneous significant accumulation of extracellular matrix structures with positive elastin-van Gieson staining was observed following foretinib/FK228 exposure. Expression analysis of treated animal tumors exhibited various changes including increased mouse transcript levels of elastin, laminin, and fibronectin. In parallel, markers for mesenchymal stroma/stem cells (MSC) including CD73 and CD90 were detectable in all mouse tumors suggesting a possible involvement of these cells in extracellular matrix restructure. Indeed, incubation of MSC with FK228 or foretinib/FK228 demonstrated morphologic alterations and enhanced expression of laminin and fibronectin. Moreover, a co-culture of MSC with lentiviral-labeled SCCOHT-1 ${ }^{\mathrm{GFP}}$ cells contributed to protection of the tumor cells against FK228-mediated cytotoxicity. Furthermore, explant cultures of SCCOHT- $1^{\mathrm{GFP}}$-induced tumors acquired an increased resistance to FK228 and a combination
\end{abstract}

Correspondence to: Professor Ralf Hass, Biochemistry and Tumor Biology Lab, Department of Obstetrics and Gynecology, Hannover Medical School, Carl-Neuberg-Str. 1, D-30625 Hannover, Germany E-mail: hass.ralf@mh-hannover.de

Key words: small cell hypercalcemic ovarian carcinoma, mesenchymal stroma/stem cells, tumor cell signaling, tumor microenvironment, chemoresistance of foretinib/FK228 in contrast to foretinib alone. Together, these data suggested that FK228-mediated extracellular matrix protein expression by MSC contributes to increased protection and enhanced resistance of SCCOHT tumors which could represent a more general mechanism of MSC during druginduced alterations of a tumor microenvironment.

\section{Introduction}

The small cell carcinoma of the ovary hypercalcemic type (SCCOHT) represents a rare form of an aggressive ovarian tumor with poor prognosis and is predominantly diagnosed in young women associated in most cases with paraendocrine hypercalcemia (1-3). Previous research has identified specific genetic alterations in SCCOHT including loss of SMARCA4 (BRG1) and SMARCA2 (BRM) functions by both, somatic and germline mutations (4-7). These SWI/SNF family proteins display ATPase and helicase activities and act as transcriptional activators by altering chromatin structures in the vicinity of target genes whereas functional loss of these proteins is associated with tumorigenic development (8). Related mutations including SMARCA4 and SMARCB1 were also observed in certain brain tumors, particularly in atypical teratoid/rhabdoid tumors (AT/RTs) and further genotypic similarities acknowledged SCCOHT as ovarian tumors with AT/RT properties (9). Accordingly, SCCOHT were suggested as malignant rhabdoid tumor of the ovary (10) whereby AT/RTs are composed of several entities requiring further discrimination (11).

Effective and standardized therapeutic approaches remain unclear for SCCOHT cancer whereby different treatment modalities such as surgery, chemotherapy, radiotherapy, and/ or high-dose chemotherapy with autologous stem cell rescue revealed a heterogeneous outcome for the patients (12). The two cellular models for this disease, SCCOHT-1 and BIN-67 have demonstrated multiple chemotherapeutic resistances by continued tumor growth of appropriate xenotransplants $(13,14)$. Moreover, in vitro and in vivo studies with these cell lines exhibited various metabolic and functional alterations during interaction with other cell populations of the tumor stroma, in particular mesenchymal stroma/stem cells (MSC). 
In general, MSC represent a heterogeneous cell population of multipotent progenitor cells which participate in structural and functional organization of connective tissue and are involved in the maintenance of tissue homeostasis. Various debates about developmental and functional properties are accompanying MSC which are almost ubiquitously present in most tissues. MSC are attracted to damaged tissue sites and wounds to modulate initial immune cell activities, to enable a neo-vascularization process, and to promote tissue repair (15-18). Likewise, aggressive tumor growth such as SCCOHT creates invasive tissue damage and an inflammatory environment whereby recruited MSC develop their natural functionality and produce certain extracellular matrix proteins to support regeneration of the damaged tissue and contribute to angiogenesis and neo-vascularization by stimulation of endothelial cells. This functionality of MSC is exploited by the tumor cells to take advantage of these conditions for further enhanced tumor growth (19-21). Indeed, previous in vitro and in vivo studies with breast cancer cells substantiate a tumor- and metastasis-promoting role of MSC within the tumor stroma by direct cell-cell interactions and/or indirectly via the release of cytokines/chemokines or microvesicles including exosomes (22-24). This is also supported by effects during culture of SCCOHT-1 cells in the presence of MSC-derived exosomes which enabled new metabolic activities in these tumor cells such as acquisition of MMP-2 and ecto5'-nucleotidase activities (25). Whereas interaction of MSC with SCCOHT-1 cells is associated with certain alteration of tumor cell properties, these MSC-mediated activities also provide the capability to re-organize the tumor microenvironment.

Therefore, in this study, we tested therapeutic compounds to treat SCCOHT-1 and BIN-67 cells and found a combination with substantial in vitro tumor cell killing. Subsequent in vivo tests of this combination in SCCOHT-1-induced mouse tumors, however, demonstrated surprising effects of tumor cell protection and accordingly, we investigated in further experiments the reasons for this divergence by focusing on distinct extracellular matrix-associated proteins and the role of MSC within the tumor microenvironment.

\section{Materials and methods}

Cell culture of tumor cells. SCCOHT-1 cells represent a spontaneously proliferating population derived from a patient with recurrent small cell carcinoma of the ovary hypercalcemic type (SCCOHT) and were maintained in RPMI-1640 with medium supplements as described previously (13).

BIN-67 cells were kindly provided by Dr Barbara Vanderhyden (University of Ottawa, Canada) and cultured with RPMI-1640 medium (Sigma-Aldrich, St. Louis, MO, USA) supplemented with $10 \%$ (v/v) fetal calf serum, $2 \mathrm{mM}$ L-glutamine, $100 \mathrm{U} / \mathrm{ml}$ penicillin and $100 \mu \mathrm{g} / \mathrm{ml}$ streptomycin (26).

Cells were cultivated at $37^{\circ} \mathrm{C}$ in a humidified atmosphere containing $5 \% \mathrm{CO}_{2}$ and tested for mycoplasma by the luminometric MycoAlert Plus mycoplasma detection kit (Lonza Inc., Rockland, ME, USA) according to the manufacturer's instructions.

Labeling of SCCOHT cells by lentiviral transduction. Wild-type SCCOHT-1 (SCCOHT-1 ${ }^{\text {wt }}$ ) cells and BIN-67 cells were transduced with a 3rd generation lentiviral SIN vector containing the GFP gene to generate SCCOHT- $1^{\mathrm{GFP}}$ cells and BIN-67 ${ }^{\mathrm{GFP}}$ cells as previously described (23). These labeled populations were used for chemosensitivity assays and for discrimination of the SCCOHT cells in co-cultures and in the mouse tissue after forming tumors and metastases.

Cell culture of primary human mesenchymal stroma/stem cells (MSC). The use of primary MSC following tissue explant culture was approved by the Ethics Committee of Hannover Medical School, Project \#443 on February 26th, 2009, and informed written consent was obtained from each patient.

MSC-like cells were isolated from explant cultures of human umbilical cords as reported previously (27) and cultured in $\alpha$-MEM medium (Sigma Chemie $\mathrm{GmbH}$, Steinheim, Germany) supplemented with $10 \%$ of allogeneic human AB-serum (commercially obtained from blood bank, University Campus Lübeck, Germany), $100 \mathrm{U} / \mathrm{ml}$ penicillin, $100 \mu \mathrm{g} / \mathrm{ml}$ streptomycin and $2 \mathrm{mM}$ L-glutamine (Sigma). For subculture, MSC were harvested by accutase (Sigma) treatment for $3 \mathrm{~min}$ at $37^{\circ} \mathrm{C}$. Co-culture of MSC and SCCOHT- $1^{\mathrm{GFP}}$ cells was performed in MSC culture medium at the indicated cell ratios for $\leq 72 \mathrm{~h}$.

Cell line authentication. Authentication of SCCOHT-1 and BIN-67 cell lines was performed by short tandem repeat (STR) fragment analysis using the GenomeLab human STR primer set (Beckman Coulter Inc., Fullerton, CA, USA). The fragment analysis demonstrated a similar STR pattern according to the STR patterns in a previous report (28).

Cytotoxicity measurements by fluoroscan assay. The proliferative capacity of SCCOHT- $1^{\mathrm{GFP}}$ cells and BIN-67 ${ }^{\mathrm{GFP}}$ cells in the presence and absence of different chemotherapeutics and corresponding $\mathrm{IC}_{50}$ measurement was performed as described previously (29). Briefly, the two tumor cell lines were incubated with different concentrations of talazoparib (BMN-673), vorinostat (SAHA), and romidepsin (FK228) (all from Selleck Chemicals LLC, Houston, TX, USA), respectively. For fluorescence measurement 3,000 cells/well were seeded with standard culture medium (100 $\mu \mathrm{l} /$ well) in flat bottom 96-well plates (Nunc/Thermo Fischer Scientific, Roskilde, Denmark) and incubated overnight to allow attachment. Thereafter, $100 \mu \mathrm{l}$ of culture medium was added to the cells as control and in further wells $100 \mu \mathrm{l}$ of culture medium containing the maximal solvent concentration was added to the cells as solvent control, respectively. Moreover, $100 \mu 1$ of the three chemotherapeutics were added to the cells and dosed in a 3-fold serial dilution, respectively. Following incubation of the cells with these chemotherapeutic compounds at different time points up to $72 \mathrm{~h}$, the medium was removed and the cells were lysed with 5\% (w/v) SDS. Afterwards, the fluorescence intensities of GFP in the cell homogenate which corresponded to the appropriate cell number of ovarian cancer cells was measured at excitation $485 \mathrm{~nm} / \mathrm{emission}$ $520 \mathrm{~nm}$ using the Fluoroscan Ascent Fl (Thermo Fisher Scientific).

Cell cycle analysis. Measurement of cell cycle distribution was performed in $5 \times 10^{5}$ SCCOHT- 1 cells and BIN-67 cells 
after culture in the absence or presence of either $0.5 \mu \mathrm{M}$ foretinib (GSK1363089; PF-02341066) (Selleck Chemicals LLC), $20 \mathrm{nM}$ FK228, or both drugs together $(0.5 \mu \mathrm{M}$ foretinib +20 nM FK228), respectively. Following treatment of SCCOHT-1 cells and BIN-67 for different time intervals, the cells were fixed in $70 \%(\mathrm{v} / \mathrm{v})$ ice-cold ethanol at $4^{\circ} \mathrm{C}$ for $24 \mathrm{~h}$. Thereafter, the fixed cells were stained with CyStain DNA 2 step kit (Sysmex Europe GmbH, Norderstedt, Germany) and filtered through a 50- $\mu \mathrm{m}$ filter. Flow cytometry analysis was performed in a Galaxy FACSan (Partec) using FloMax analysis software (Partec).

Immunohistochemical analysis of SCCOHT mouse tumors. Immunohistochemistry was performed on an automated staining instrument (Benchmark Ultra; Ventana, Tuscon, AZ, USA) using the CC1 mild antigen retrieval procedure. Paraformaldehyde-fixed thin tissue sections were stained for HE, Ki67, and Elastin-van-Gieson.

Transcript analysis by $R T-P C R$. Total RNA was isolated from 3 control and 3 treated SCCOHT-1 tumor tissues using RNeasy Mini kit (Qiagen, Hilden, Germany) according to the manufacturer's instructions. RNA $(1 \mu \mathrm{g})$ was reverse transcribed into cDNA using $500 \mu \mathrm{M}$ of dNTP (R0193), $5 \mu \mathrm{M}$ Oligo(dT)18 primer (S0132), $5 \mu \mathrm{M}$ Random Hexan primer (S0142), 1 U RiboLock ${ }^{\mathrm{TM}}$ RNase Inhibitor (E00381) and $5 \mathrm{U}$ RevertAid $^{\mathrm{TM}}$ M-MuLV Reverse Transcriptase (EP0441) in the supplied reaction buffer (all reagents from Thermo Scientific, Schwerte, Germany). The cDNA reactions were performed for $10 \mathrm{~min} / 25^{\circ} \mathrm{C}, 1 \mathrm{~h} / 37^{\circ} \mathrm{C}$ and stopped at $72^{\circ} \mathrm{C}$ for $10 \mathrm{~min}$. As a template $2.5 \mu \mathrm{l}$ of cDNA was used with following specific primers (all primers customized by Eurofins, MWG GmbH, Ebersberg, Germany): CD73 (sense, 5'-CGC AAC AAT GGC ACA ATT AC-3'; antisense, 5'-CTC GAC ACT TGG TGC AAA GA-3'; amplification product 241 bp) (25); CD90 (sense, 5'-GGA CTG AGA TCC CAG AAC CA-3'; antisense, 5'-ACG AAG GCT CTG GTC CAC TA-3'; amplification product 124 bp) (25); human VEGF-A (sense, 5'-CCT CAG TGG GCA CAC ACT CC-3'; antisense, 5'-CGA AAC CAT GAA CTT TCT GC-3' amplification product 302 bp) (28); human cyclin D1 (sense, 5'-CTT CCT CTC CAA AAT GCC AG-3'); antisense, 5'-AGA GAT GGA AGG GGG AAA GA-3' amplification product $568 \mathrm{bp}$ ) (30); mouse VEGF-R2 (sense, 5'-ATA ACC TGG CTG ACC CGA TTC -3'; antisense, 5'-TCG GTG ATG TAC ACG ATG CC-3' amplification product 614 bp) (28); mouse laminin B2 (sense, 5'-AGA AGG CAG AGA CAG TCC AAG C-3'; antisense, 5'-GTA TTG GTC ACC TAC TTG TTC C-3' amplification product 328 bp (31); mouse elastin (sense, 5'-ACT AAG CTG GCT GGG CAT AC-3'; antisense, 5'-CCA AAG AGC ACA CCA ACA ATC-3' amplification product 282 bp; mouse fibronectin-1 (sense, 5'-CAG TGT TGG GCA ACA AAT GA-3'; antisense, 5'-GGCATGTGAGCTTAAAGCCA-3' amplifications product 569 bp) (32); GAPDH as a control PCR (sense, 5'-ACC ACA GTC CAT GCC ATC AC-3'; antisense, 5'-TCC ACC ACC CTG TTG CTG TA-3'; amplification product 452 bp).

PCR reactions included $0.2 \mu \mathrm{M}$ of each primer, $200 \mu \mathrm{M}$ of dNTP (R0193, Thermo Scientific) and 0.05 U Taq DNA polymerase (EPO402, Thermo Scientific) in the supplied reaction buffer. PCR cycling conditions were performed
$30 \mathrm{sec}$ at $94^{\circ} \mathrm{C}, 1 \mathrm{~min}$ at $60^{\circ} \mathrm{C}$ and $72^{\circ} \mathrm{C}$ for $1 \mathrm{~min}$, respectively, including an initial $30 \mathrm{sec}$ denaturation step at $94^{\circ} \mathrm{C}$ and a final 10 -min extension step at $72^{\circ} \mathrm{C}$ ( 35 cycles). Aliquots of $25 \mu \mathrm{l}$ of each RT-PCR product were separated on a $2 \%$ agarose gel including the standard GeneRuler 100 bp DNA Ladder (Thermo Scientific) and visualized by GelRed ${ }^{\mathrm{TM}}$ (Biotium Inc., Hayward, CA, USA) staining.

In vivo experiments. Animal research using $\mathrm{NOD}^{\text {scid }}$ mice was carried out by following internationally recognized guidelines on animal welfare and was approved by the institutional licensing committee ref. \#33.14-42502-04-12/0814 on June 26th, 2012.

Approximately $3 \times 10^{6}$ SCCOHT- $1^{\mathrm{GFP}}$ cells were injected subcutaneously into $\sim 5$ week-old-female NODscid mice. Within 10 days, all SCCOHT-1-injected mice had developed small subcutaneous tumors. A therapeutic approach was performed with a combined therapy of foretinib and FK228. In detail, a systemic therapy was performed by oral application of $200 \mu \mathrm{l}$ foretinib $(25 \mathrm{mg} / \mathrm{kg}$ ) (Selleck Chemicals LLC) dissolved in $30 \%(\mathrm{v} / \mathrm{v})$ propylene glycol, $5 \%(\mathrm{v} / \mathrm{v})$ Tween-80, and $65 \%(\mathrm{v} / \mathrm{v})$ of a $5 \%(\mathrm{w} / \mathrm{v})$ dextrose solution in $\mathrm{H}_{2} \mathrm{O}$. Oral application was performed using plastic feeding tubes (18 ga $\mathrm{x}$ $30 \mathrm{~mm}$ ) (Instech Laboratories, Plymouth, PA, USA) whereby the amount of applied foretinib was half of that used in previous experiments (28). Other in vivo mouse experiments in recent studies were performed even at 3- to 4-fold higher foretinib concentrations of $60-100 \mathrm{mg} / \mathrm{kg}$ (33) whereas this compound is administered to patients between 3.6 and $4.5 \mathrm{mg} / \mathrm{kg}$ in clinical studies. In addition to a daily foretinib treatment, the mice received an intraperitoneal application of $20 \mu \mathrm{g}$ FK228 dissolved in $500 \mu \mathrm{l}$ of $0.9 \% \mathrm{NaCl}$ from a DMSO stock solution with a final concentration of $0.74 \%$ (v/v) DMSO every $72 \mathrm{~h}$. Control tumor-carrying mice received $200 \mu \mathrm{l}$ of a daily oral application of $30 \%(\mathrm{v} / \mathrm{v})$ propylene glycol, $5 \%(\mathrm{v} / \mathrm{v})$ Tween-80, and $65 \%(\mathrm{v} / \mathrm{v})$ of a $5 \%(\mathrm{w} / \mathrm{v})$ dextrose solution in $\mathrm{H}_{2} \mathrm{O}$ and an intraperitoneal application of $500 \mu \mathrm{l}$ with $0.74 \%$ (v/v) DMSO in $0.9 \% \mathrm{NaCl}$ every $72 \mathrm{~h}$.

Following 10 days of therapy, 4 mice of the treated tumors and 4 mice with a control tumor were sacrificed by cervical dislocation. The GFP-positive tumors were dissected under UV light, washed in PBS, weighed and either cultured in a primary explant culture for chemosensitivity testing, or RNA extracted for subsequent PCR analysis, or fixed in $4 \%$ glutardialdehyde solution for histopathological evaluations.

\section{Results}

SCCOHT- $1^{\text {wt }}$ cells were developed in our lab from a recurrent SCCOHT tumor biopsy and SCCOHT-1 ${ }^{\mathrm{GFP}}$ cells were generated from SCCOHT- $1^{\text {wt }}$ cells after lentiviral GFP transduction and clonal selection. Functional differences revealed an enhanced in vitro proliferative capacity of SCCOHT- ${ }^{\mathrm{GFP}}$ cells compared to SCCOHT- $1^{\mathrm{wt}}$ cells and a significantly accelerated in vivo tumor development in NODscid mice (tumor within $\sim 10$ days $/ 2 \times 10^{6}$ subcutaneously injected SCCOHT- $1^{\mathrm{GFP}}$ cells) compared to the corresponding wild-type population (tumor after $>8$ weeks $/ 2 \times 10^{6}$ subcutaneously injected SCCOHT- ${ }^{\mathrm{wt}}$ cells). Since reference cell lines are not available, an extended STR analysis was performed to substantiate the fragment 
Table I. Comparative STR fragment analysis was performed in SCCOHT-1 cells, SCCOHT-1 ${ }^{\text {GFP }}$ cells, and different patientoriginating tissues including PBMC, patient normal tissue and patient SCCOHT tumor tissue.

\begin{tabular}{lccccc}
\hline STR fragment & SCCOHT $^{\text {wt }}$ & SCCOHT $^{\text {GFP }}$ & Patient PBMC & Patient normal tissue & Patient tumor tissue \\
\hline Penta D A1 & 12 & 12 & 12 & 12 & 12 \\
Penta D A2 & 15 & 15 & 15 & 15 & 15 \\
Penta E A1 & 10 & 10 & 10 & 10 & 10 \\
Penta E A2 & 13 & 13 & 13 & 13 & X-chr \\
AMEL A1 & X-chr & X-chr & X-chr & X-chr & X-chr \\
AMEL A2 & X-chr & X-chr & X-chr & X-chr & 10 \\
CSF1PO A1 & 10 & 10 & 10 & 10 & 11 \\
CSF1PO A2 & 11 & 11 & 11 & 11 & 8 \\
D13S317 A1 & 8 & & 8 & 8 & 12 \\
D13S317 A2 & 12 & 12 & 12 & 12 & 13 \\
D16S539 A1 & 9 & 9 & 9 & 13 & 13 \\
D16S539 A2 & 13 & 13 & 13 & 13 & 13 \\
D18S51 A1 & 13 & 13 & 13 & 13 & 13 \\
D18S51 A2 & 13 & 13 & 13 & 15 & 10 \\
D3S1358 A1 & 15 & 15 & 15 & 17 & 11 \\
D3S1358 A2 & 17 & 17 & 17 & 10 & 13 \\
D7S820 A1 & 10 & 10 & 10 & 11 & 14 \\
D7S820 A2 & 11 & 11 & 11 & 13 & 7 \\
D8S1179 A1 & 13 & 13 & 13 & 14 & 8 \\
D8S1179 A2 & 14 & 14 & 14 & 7 & 8 \\
TH01 A1 & 7 & 7 & 7 & 8 & 9 \\
TH01 A2 & 8 & 8 & 8 & 8 & 9 \\
TPOX A1 & 8 & 9 & 9 & 9 & 13 \\
TPOX A2 & 9 & & & & 13 \\
\hline
\end{tabular}

patterns of these unique SCCOHT-1 populations. Therefore, SCCOHT- $1^{\text {wt }}$ cells were tested together with SCCOHT-1 ${ }^{\text {GFP }}$ cells and various tissues including PBMC, normal ovarian tissue and SCCOHT tumor tissue from the originating patient. All 11 gene fragments and the gender analysis revealed similar STR pattern in both cell populations and the three tissues, respectively, with the exception that one fragment of D13S317 remained undetectable in transfected SCCOHT- $1^{\text {GFP }}$ cells (Table I).

Loss of SMARCA4 (BRG1) and SMARCA2 (BRM) in SCCOHT contributes to altered chromatin remodeling capabilities and tumor growth which is also property of the corresponding cellular models. Therefore, certain DNA-associated proteins were targeted by appropriate inhibitors in the two only available cell lines for this disease to date, known as SCCOHT-1 and BIN-67. Following lentiviral GFP-labeling, the SCCOHT- ${ }^{\text {GFP }}$ and BIN-67 ${ }^{\text {GFP }}$ cells were used in a fluorescence-based assay and treated with different chemotherapeutic compounds including the poly-ADP-ribose polymerase (PARP) inhibitor BMN-673 which prevents PARP-mediated DNA repair of single strand DNA breaks via the base-excision repair pathway and thereby enhances the accumulation of DNA damage and promotes genomic instability. Moreover, deacetylated histones are involved in reduced transcriptional activities associated with enhanced DNA protection and heterochromatin remodeling which can be blocked by appropriate histon deacetylase (HDAC) inhibitors such as SAHA and FK228, respectively. Both tumor cell populations demonstrated low responsiveness to BMN-673 with an $\mathrm{IC}_{50}$ of $1.65 \times 10^{-6} \mathrm{M}$ for SCCOHT- ${ }^{\text {GFP }}$ cells (Fig. $1 \mathrm{~A}$, upper left panel) and an $\mathrm{IC}_{50}$ of $1.16 \times 10^{-5} \mathrm{M}$ for BIN-67 ${ }^{\text {GFP }}$ cells (Fig. 1A, upper right panel) after $72 \mathrm{~h}$. Likewise, high $\mathrm{IC}_{50}$ values were obtained for SAHA with $2.86 \times 10^{-6} \mathrm{M}$ for SCCOHT- $\mathrm{G}^{\mathrm{GFP}}$ cells (Fig. 1A, middle left panel) and $6.9 \times 10^{-6} \mathrm{M}$ for BIN-67 $67^{\mathrm{GFP}}$ cells (Fig. 1A, middle right panel) after $72 \mathrm{~h}$. In contrast, a markedly elevated sensitivity of the tumor cells was observed for the HDAC inhibitor FK228 with an $\mathrm{IC}_{50}$ of $6.29 \times 10^{-9} \mathrm{M}$ for SCCOHT- $1^{\text {GFP }}$ cells after $72 \mathrm{~h}$ (Fig. 1A, lower left panel) and an $\mathrm{IC}_{50}$ of $3.63 \times 10^{-10} \mathrm{M}$ for BIN-67 ${ }^{\mathrm{GFP}}$ cells after $144 \mathrm{~h}$ (Fig. 1A, lower right panel).

Previous research has demonstrated effective tumor regression of SCCOHT-induced mouse tumors by high calcium together with the microtubule inhibitory epothilone B (29) or by the c-Met inhibitor foretinib (28). Considering the promising in vitro results for the HDAC inhibitor FK228 (Fig. 1A, lower panels), a combination of these differentially functional antitumor agents was tested in a fluorescence-based proliferation assay using the two GFP-labeled SCCOHT cell 
A

BMN-673 (IC50)

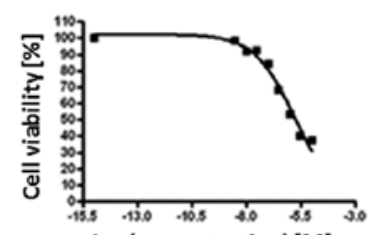

Log(concentration) [M]

SAHA (IC50)

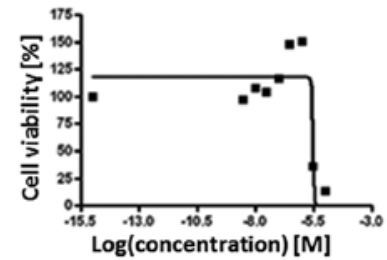

FK228 (IC50)

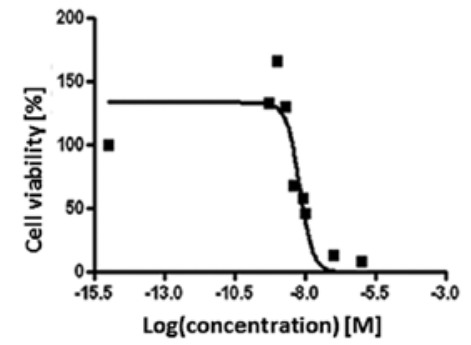

SCCOHT-1

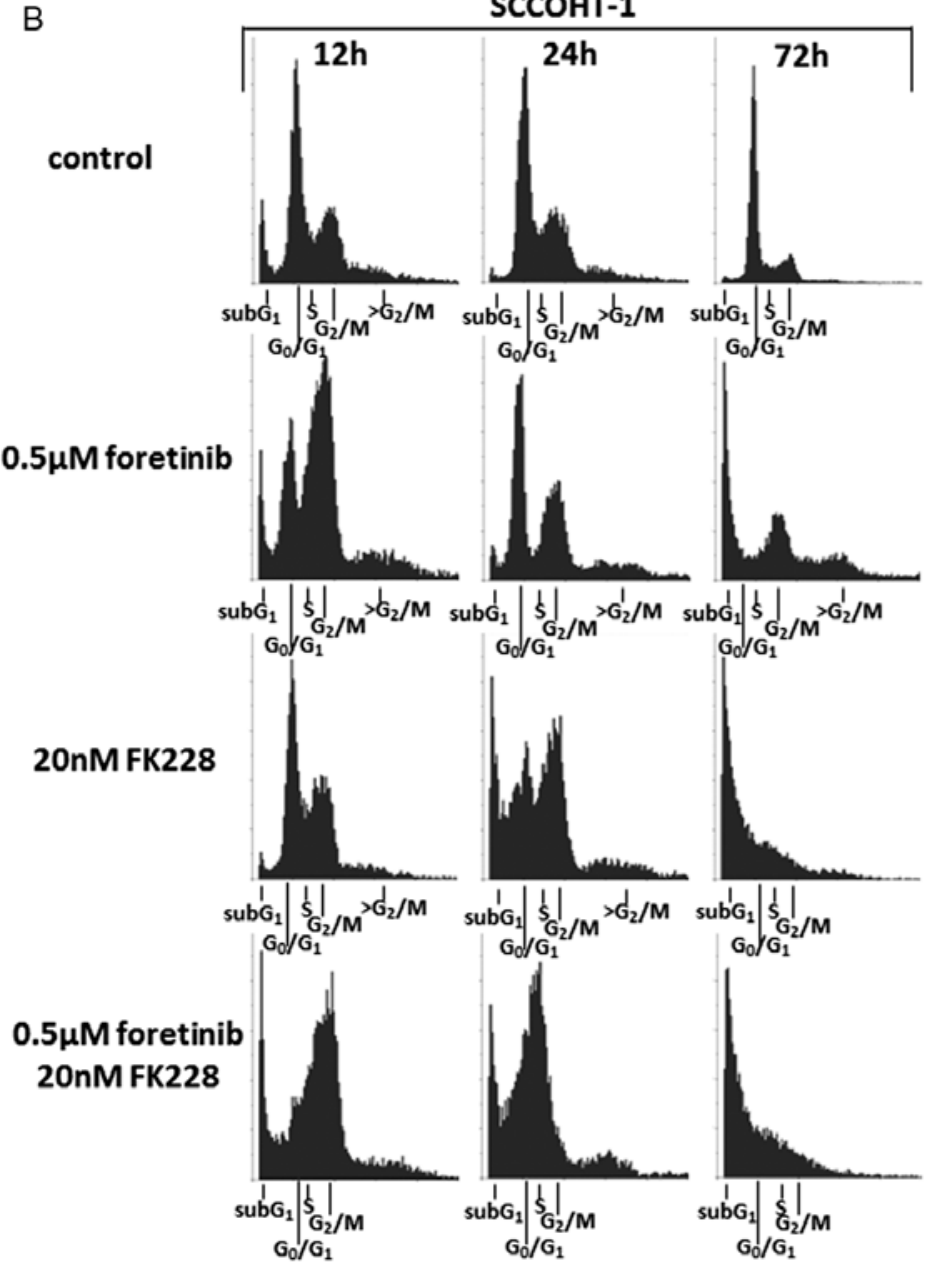

BIN-67 cells
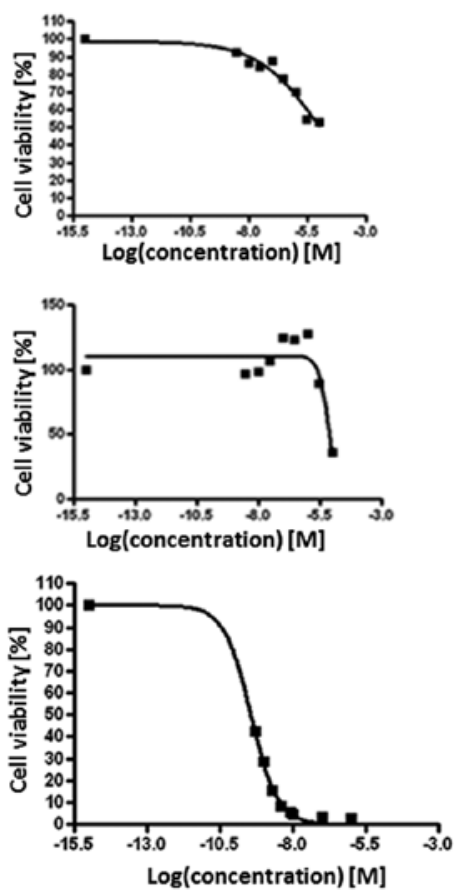

BIN-67
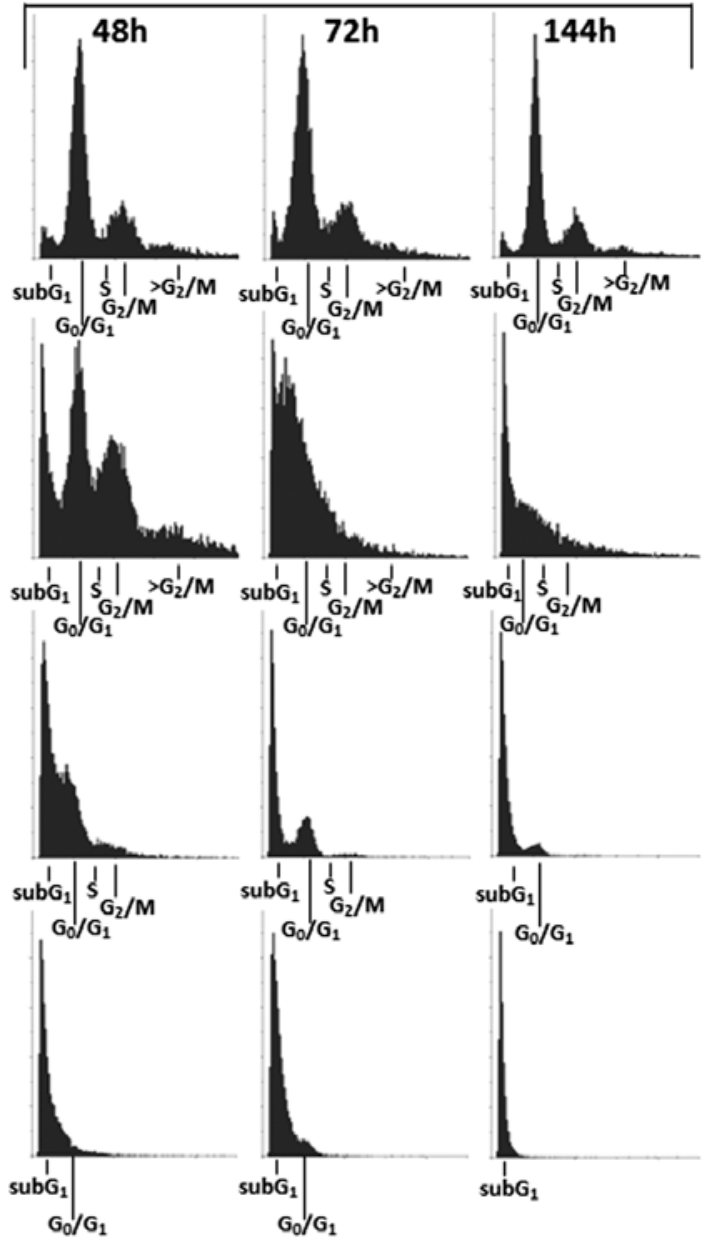

Figure 1. (A) Chemosensitivity of SCCOHT cells. BIN-67 ${ }^{\mathrm{GFP}}$ and SCCOHT-1 ${ }^{\mathrm{GFP}}$ cells were exposed to different concentrations of the PARP inhibitor BMN-673 and to the HDAC inhibitors SAHA and FK228, respectively. Analysis of a drug-dose response to define $\mathrm{IC}_{50}$ concentrations for these three compounds was performed using GraphPad Prism 6. For calculation of the drug-dose response curves, the data were normalized to the cells-only control in culture medium and to the maximal solvent (DMSO) concentration control of the compounds, respectively. (B) Cell cycle analysis was performed following treatment of SCCOHT-1 cells for 12-72 h and incubation of BIN-67 cells for 48-144 h with either $0.5 \mu \mathrm{M}$ foretinib, or $20 \mathrm{nM}$ FK228, or both compounds together. 


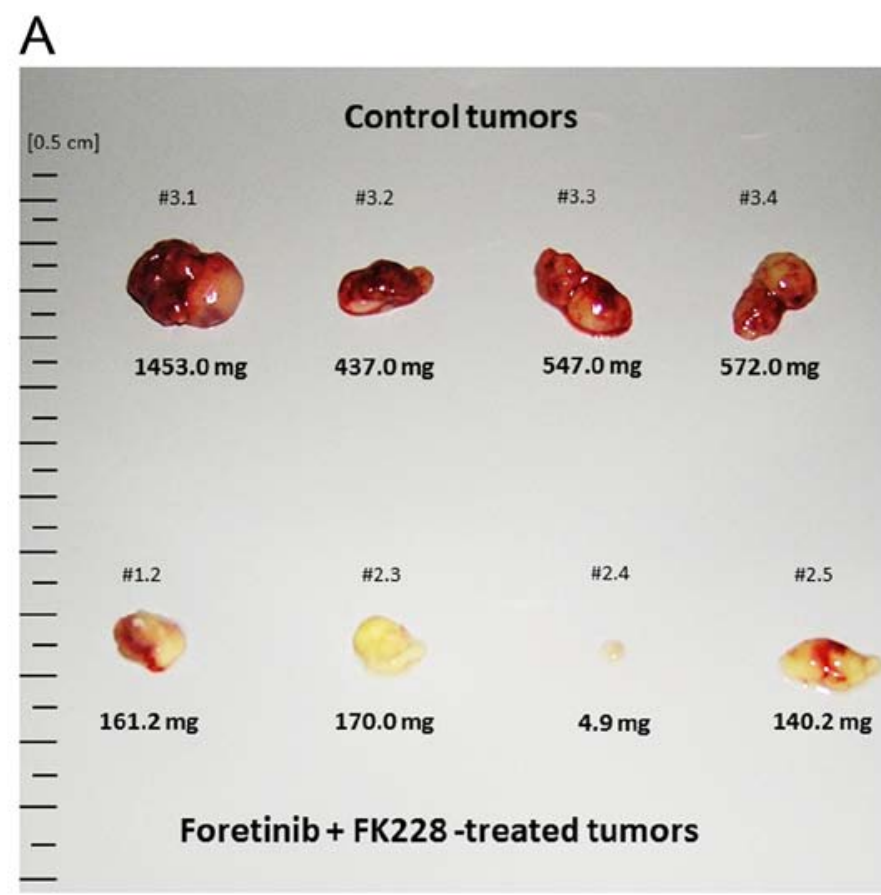

\section{Lung metastases of SCCOHT-1 GFP}

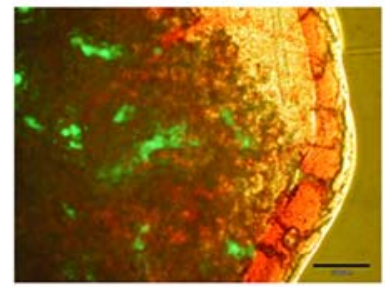

B

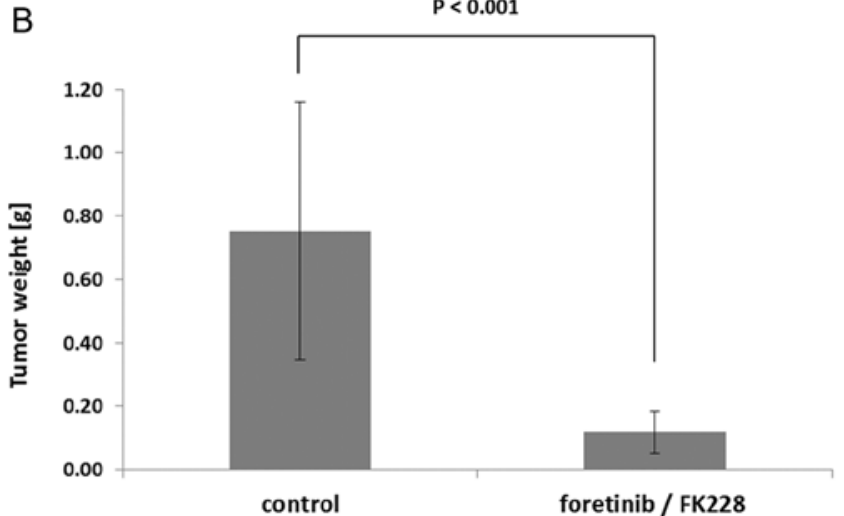

C

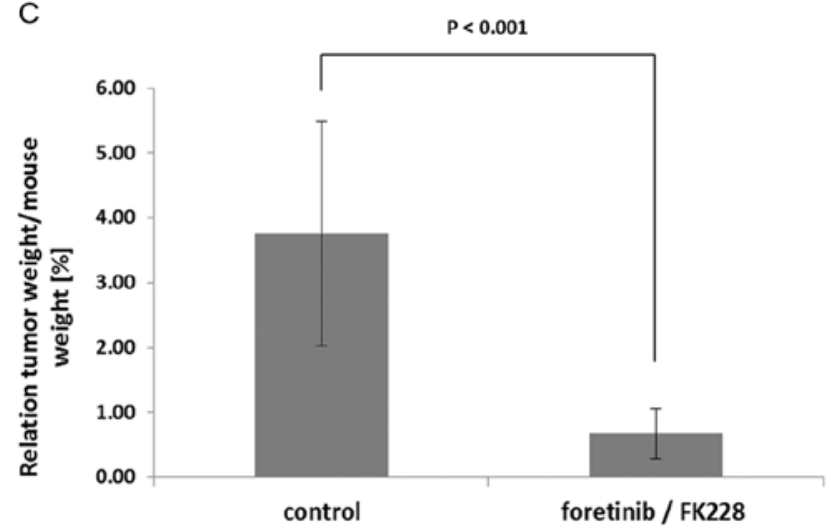

Figure 2. (A) SCCOHT-1 ${ }^{\text {GFP }}$-induced tumors in NODscid mice were treated with a daily oral application of $200 \mu 1$ foretinib at a concentration of $25 \mathrm{mg} / \mathrm{kg}$ and an additional intraperitoneal injection of $500 \mu 1$ with $20 \mu \mathrm{g}$ FK228 every $72 \mathrm{~h}$. Tumors in control mice received a similar treatment with the appropriate solvents. After 10 days of therapy, 4 treated mice and 4 control mice were euthanized by cervical dislocation and the GFP-positive tumors were dissected under UV light and briefly washed in PBS for documentation (left image). Evaluation of the mouse organs under UV light also revealed metastasis in the lung after treatment (right image). (B) Following 10 days of subsequent treatment of SCCOHT-1 ${ }^{\text {GFP }}$-induced NODscid mouse tumors either with the appropriate drug solvents (control) or with foretinib/FK228, the SCCOHT- ${ }^{\text {GFP }}$ tumor weight was measured and calculated as the mean \pm SD for control tumors (n=4) and treated tumors $(\mathrm{n}=4)$. Statistical analysis was conducted by unpaired Student's $\mathrm{t}$-test $(\mathrm{P}<0.001)$. (C) The relation of SCCOHT- $1^{\text {GFP }}$ tumor weight/mouse weight was calculated after 10 days of subsequent treatment as the mean \pm SD for control tumors $(n=4)$ and foretinib/FK228-treated tumors $(n=4)$. Statistical analysis was conducted by unpaired Student's t-test ("P $<0.001)$.

lines. In these experiments, $0.5 \mu \mathrm{M}$ foretinib was applied with epothilone B (2 and $10 \mathrm{nM}$, respectively) and FK228 (20 and $100 \mathrm{nM}$, respectively) either alone, or in a two drug or three drug combination for 24,72 and $120 \mathrm{~h}$, respectively, in SCCOHT- ${ }^{\text {GFP }}$ cells and BIN-67 $67^{\text {GFP }}$ cells. One of the most effective growth inhibition in both cell lines with low drug concentration was observed with a combination of $0.5 \mu \mathrm{M}$ foretinib and $20 \mathrm{nM}$ FK228 demonstrating synergistic effects as compared to both compounds alone and revealed only $1.31 \pm 0.01 \%(\mathrm{n}=3)$ of proliferating SCCOHT- $1^{\mathrm{GFP}}$ cells and $5.44 \pm 0.2 \%(n=3)$ of proliferating BIN-67 ${ }^{\mathrm{GFP}}$ cells after $120 \mathrm{~h}$. This growth inhibition of $\sim 95 \%$ in BIN-67 ${ }^{\mathrm{GFP}}$ cells and $\sim 98 \%$ in SCCOHT-1 ${ }^{\text {GFP }}$ cells was also confirmed by cell cycle analysis. Stimulation of SCCOHT-1 cells with $0.5 \mu \mathrm{M}$ foretinib for $\geq 72 \mathrm{~h}$ was associated with a $\mathrm{G} 2 / \mathrm{M}$ accumulation and populations with even more DNA content $(>\mathrm{G} 2 / \mathrm{M})$ compared to controls. In contrast, SCCOHT-1 treatment with $20 \mathrm{nM}$ FK 228 or a combination of $0.5 \mu \mathrm{M}$ foretinib and $20 \mathrm{nM}$ FK228 demonstrated an initial G2/M arrest with subsequent accumulation of dead or dying cells in a sub-G1 phase after $72 \mathrm{~h}$ (Fig. 1B, left histograms). The slower proliferating BIN-67 cells were observed for $\geq 144 \mathrm{~h}$ and exhibited an initial $\mathrm{G} 2 / \mathrm{M}$ accumulation with $0.5 \mu \mathrm{M}$ foretinib after $48 \mathrm{~h}$ followed by G1 arrest and some cells in sub-G1. Incubation of BIN-67 cells with $20 \mathrm{nM}$ FK228 or a combination of $0.5 \mu \mathrm{M}$ foretinib and $20 \mathrm{nM}$ FK228, however, was accompanied by little if any detectable cells in the proliferative cell cycle and an accumulation of dead or dying cells in a sub-G1 phase after $144 \mathrm{~h}$ 

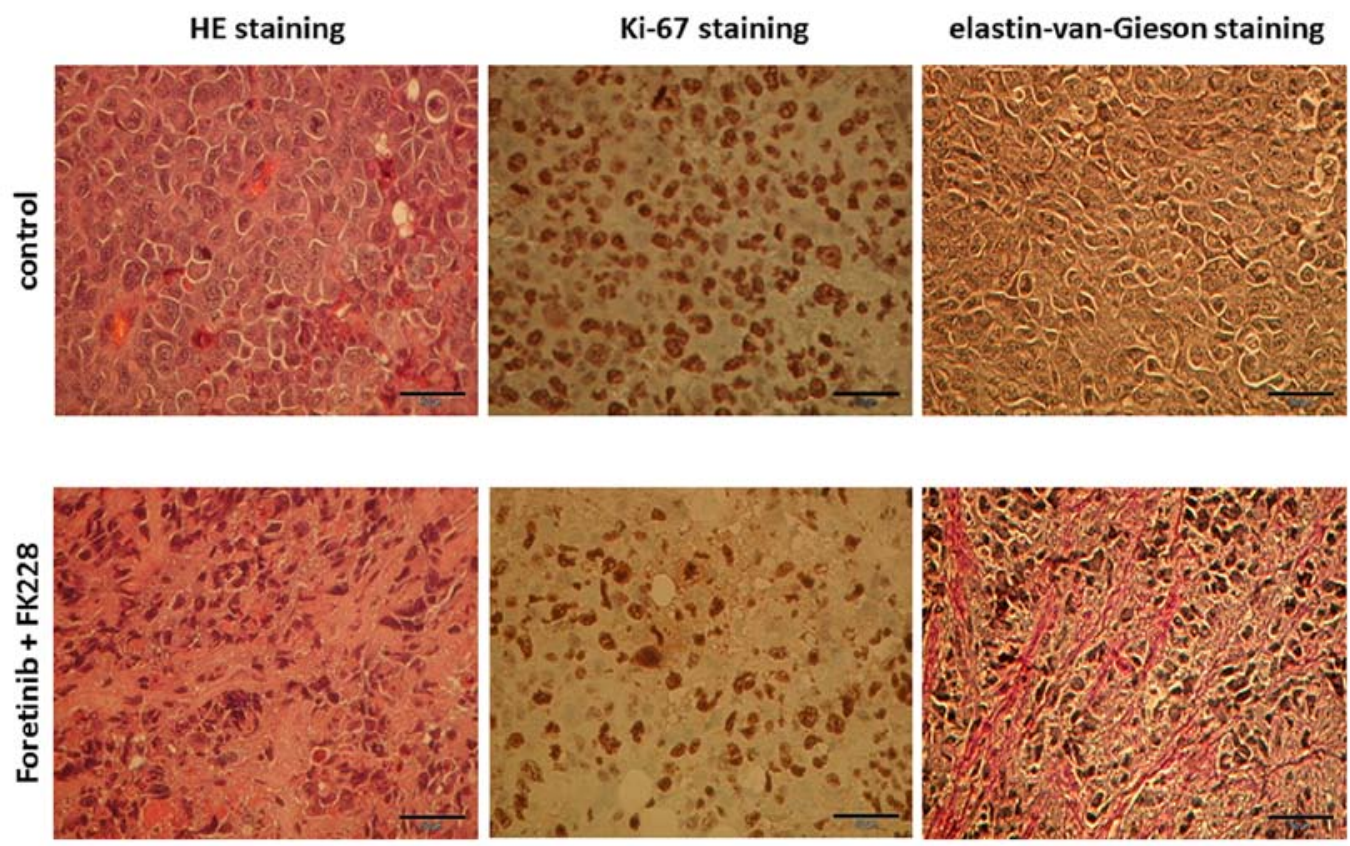

Figure 3. Thin tissue sections from the SCCOHT- $1^{\text {GFR }}$ control tumors and the (foretinib + FK228)-treated tumors were fixed in paraformaldehyde and stained for HE, Ki-67, and Elastin-van-Gieson. A representative selection from 4 different control tumors and 4 treated tumors is shown. Bars, $50 \mu \mathrm{m}$.

(Fig. 1B, right histograms). Together, these data demonstrated an efficient in vitro tumor cell killing of $>95 \%$ by a combination of $0.5 \mu \mathrm{M}$ foretinib with $20 \mathrm{nM}$ FK228.

To confirm these findings in vivo, SCCOHT- $1^{\mathrm{GFP}}$-induced tumors in NODscid mice were treated with a combination of an intraperitoneal FK228 application every $72 \mathrm{~h}$ and a daily oral foretinib application over a period of 10 days. Simultaneously, control mice were treated with the appropriate solvents. Although tumor size was significantly reduced in the combined treatment (Fig. 2A, left panel), distant organ metastasis could be observed as documented by the distribution of green fluorescence from SCCOHT- $1^{\mathrm{GFP}}$ tumor cells within lung tissue (Fig. 2A, right panel). Whereas five mice died in the course of the experiment for unknown reasons, there was little if any change in the body weight of the control mice or during chemotherapeutic application within the 10 days of treatment. However, a 6.3-fold reduction in tumor weight was measured after treatment with $\sim 0.752 \pm 0.408 \mathrm{~g}(\mathrm{n}=4)$ in control tumors compared to $0.119 \pm 0.067 \mathrm{~g}(\mathrm{n}=4)$ in foretinib/FK228-exposed tumors (Fig. 2B). Likewise, the relation of tumor weight to mouse weight revealed $3.763 \pm 1.727 \%(n=4)$ in control tumors compared to $0.675 \pm 0.386 \%(n=4)$ in foretinib/FK228-treated tumors which displayed a 5.6-fold tumor reduction (Fig. 2C).

Histopathological evaluation of the mouse tumors by hematoxylin/eosin (HE) revealed an increased vascularization of control tumors compared to foretinib/FK228 treatment (Fig. 3, left panels). Likewise, expression of the proliferation marker Ki-67 was markedly enhanced in control tumors (Fig. 3, middle panels). In contrast, a significant amount of extracellular matrix structures with positive staining for elastin-van-Gieson appeared predominantly in the foretinib/FK228-treated tumor (Fig. 3, right panels).

Transcripts of three different control tumors were compared to three foretinib/FK228-treated mouse tumors

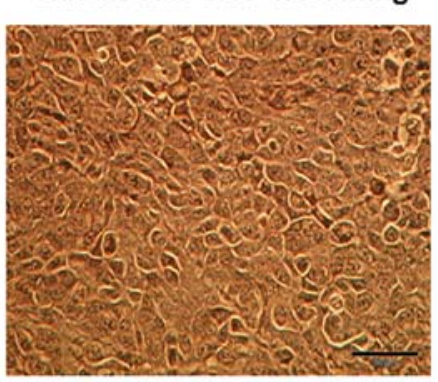



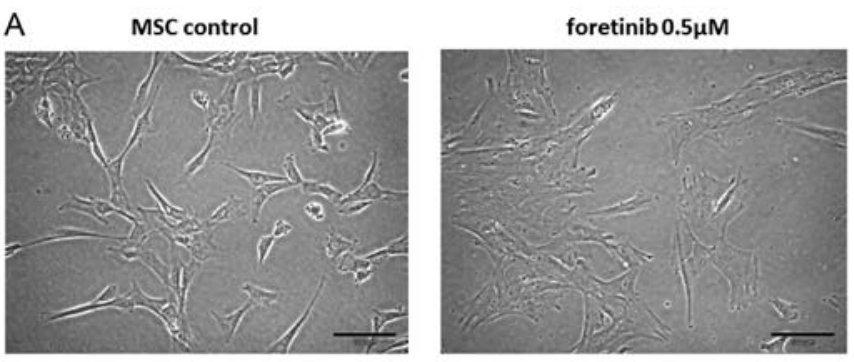

foretinib $0.5 \mu \mathrm{M}$ + FK228 100nM
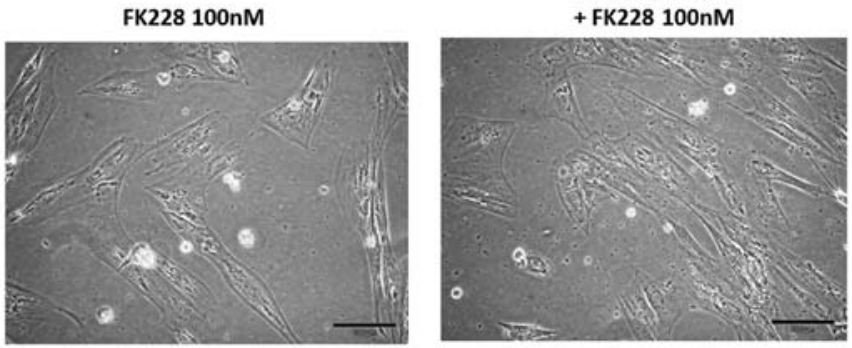

B

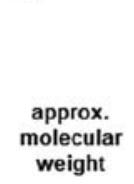

$68 \mathrm{kDa}$

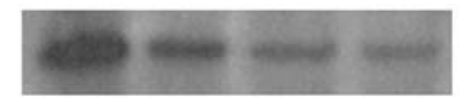

MMP-9

$260 \mathrm{kDa}$

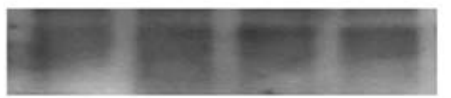

fibronectin

$220 \mathrm{kDa}$

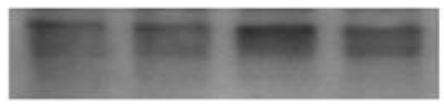

laminin

$37 \mathrm{kDa}$

GAPDH

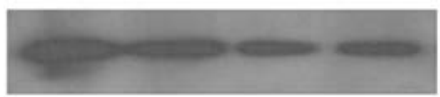

Figure 5. (A) Representative micrographs after incubation of mesenchymal stroma/stem cell (MSC) populations with $0.5 \mu \mathrm{M}$ foretinib and $100 \mathrm{nM}$ FK228 alone or in combination demonstrate different cell morphology particularly in FK228-treated cells after $72 \mathrm{~h}$. Bars, $100 \mu \mathrm{m}$. (B) Western blot analysis was carried out with $20 \mu \mathrm{g}$ of total cellular protein after stimulation of MSC with $0.5 \mu \mathrm{M}$ foretinib and $100 \mathrm{nM}$ FK228 alone or in combination for $72 \mathrm{~h}$. GAPDH was used as equal loading control.

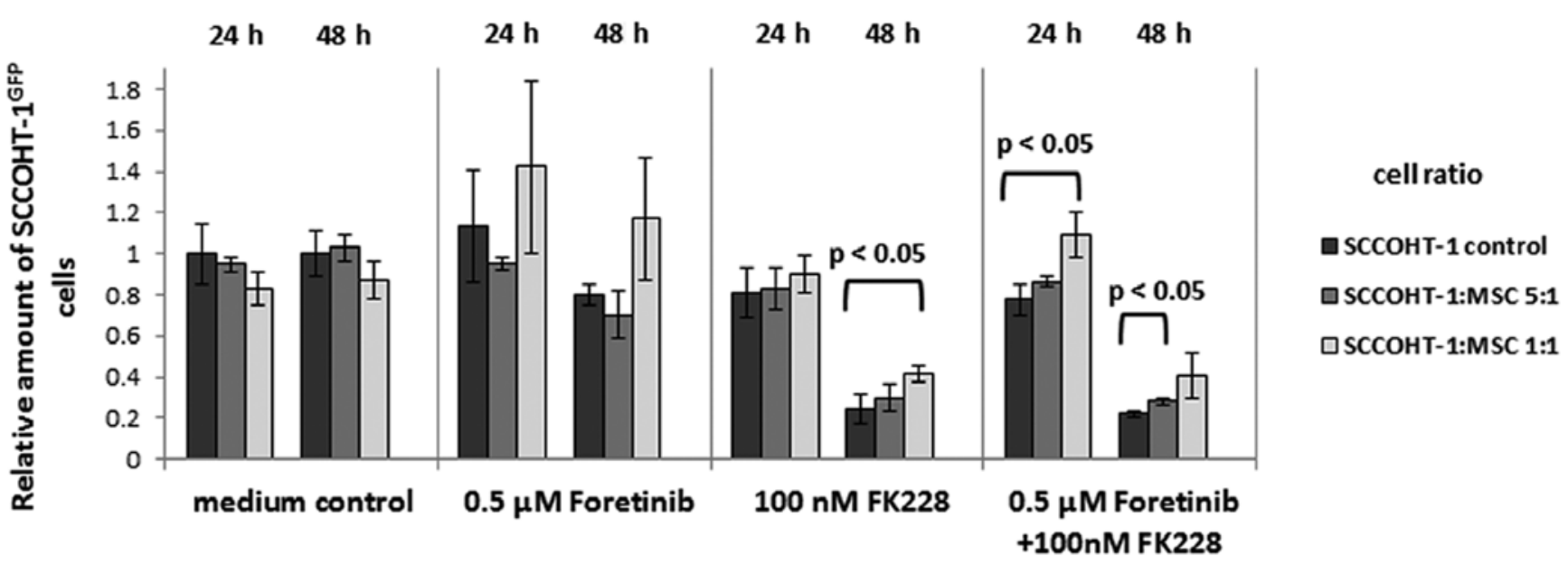

Figure 6. Co-cultures in microtiter plates were performed using initially 1,000 SCCOHT-1 ${ }^{\mathrm{GFP}}$ cells/well together with variable amounts of MSC to reach the indicated cell ratios. The co-cultures compared to a corresponding mono-culture with initially 1,000 SCCOHT- $1^{\text {GFP }}$ cells/well were exposed to $0.5 \mu \mathrm{M}$ foretinib, or $100 \mathrm{nM} \mathrm{FK} 228$ alone, or a combination of both drugs for 24 and $48 \mathrm{~h}$ and the amount of tumor cells was determined in a fluoroscan assay. Data represent the mean $\pm \mathrm{SD}(\mathrm{n}=3)$ and statistical analysis was conducted to determine the appropriate significance (p) using the unpaired Student's t-test.

growth factor-A (VEGF-A). With respect to mouse-specific gene expression derived from appropriate mouse MSC and further cell populations within the tumor microenvironment, a significant down-modulation of the murine vascular endothelial growth factor receptor-2 (m-VEGF-R2) was detectable in the treated mouse tumors. Vice versa, mRNAs of various extracellular matrix proteins including laminin, elastin, and fibronectin were upregulated in the mouse tissue of foretinib/FK228-treated tumors suggesting enhanced expression of extracellular matrix structures by cells of the tumor microenvironment where MSC play a major role. Indeed, similar levels of the MSC-specific markers CD73 and CD90 were detectable in all tumor specimens. Unaltered expression levels of GAPDH served as a loading control (Fig. 4).
Based upon these data, a potential direct contribution of MSC to changes in extracellular matrix protein expression and a possible role of MSC to protect the tumor cells were investigated by appropriate western blots and co-culture experiments.

Exposure of MSC cultures to $0.5 \mu \mathrm{M}$ foretinib for $72 \mathrm{~h}$ revealed a similar morphology of a singularized and differently shaped cell culture compared to untreated control cells. In contrast, treatment of MSC with either 100 nM FK228 alone or a combination of both drugs foretinib/FK228 was associated with a formation of paralleled cell aggregates displaying fibroblast-like extensions and a marked accumulation of cellassociated filament structures (Fig. 5A).

Western blot analysis demonstrated a reduced expression of the matrix-restructuring enzyme MMP-9 after treatment 


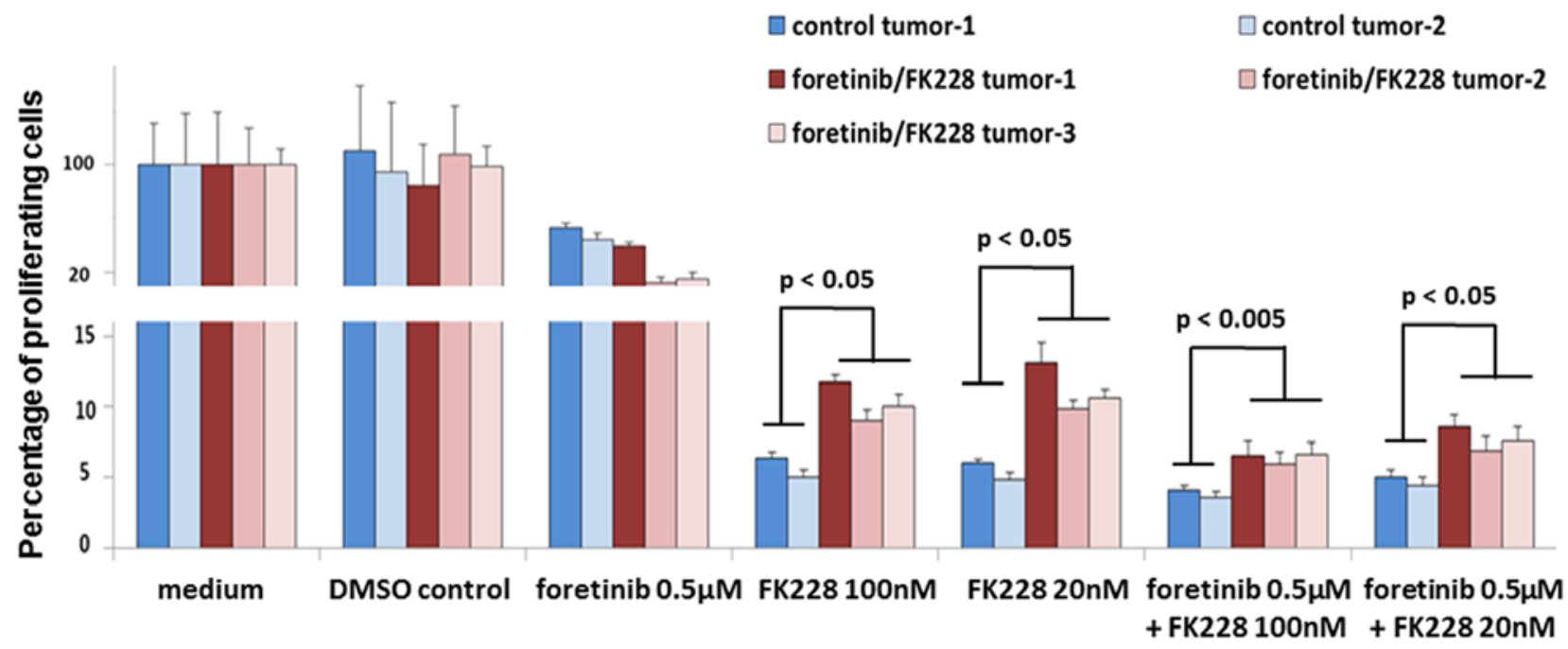

Figure 7. Analysis of chemotherapeutic responsiveness was performed in cells from explant cultures after re-culture of two NODscid mouse control tumors and three foretinib/FK228-treated tumors. Explant culture cells from the different mouse tumors were plated in microtiter plates at 3,000 cells/well and incubated with $0.5 \mu \mathrm{M}$ foretinib, $100 \mathrm{nM}$ or $20 \mathrm{nM} \mathrm{FK} 228$, or a combination of both drugs for $72 \mathrm{~h}$, respectively. Thereafter, the amount of GPF-positive tumor cells was quantified in a fluoroscan assay and normalized to the corresponding control. Data represent the mean $\pm \mathrm{SD}(\mathrm{n}=3)$ and statistical analysis was conducted by unpaired Student's t-test to evaluate the appropriate significance (p) between the different stimulation groups.

with $0.5 \mu \mathrm{M}$ foretinib, $100 \mathrm{nM}$ FK228 or a combination of both. Little if any change was observed in the expression of structural proteins of the connective tissue within the extracellular matrix including fibronectin and laminin in MSC and foretinib-exposed MSC. However, treatment of MSC with FK228 or a combination of foretinib with FK228 was associated with enhanced expression of fibronectin and laminin. Unaltered levels of GAPDH served as loading control (Fig. 5B).

A co-culture of MSC with SCCOHT- $1^{\text {GFP }}$ cells at a cell ratio of 1:5 revealed a marked increase in the amount of tumor cells compared to a corresponding SCCOHT- $1^{\mathrm{GPP}}$ monoculture in the presence of $100 \mathrm{nM}$ FK228 after 24 and $48 \mathrm{~h}$. Similar results were obtained after exposure of the mono- and co-cultures to a combination of $0.5 \mu \mathrm{M}$ foretinib $+100 \mathrm{nM}$ FK228 (Fig. 6). These effects of an elevated amount of tumor cells in the chemotherapeutics-treated co-culture compared to the SCCOHT- ${ }^{\text {GFP }}$ mono-culture was even more pronounced in the presence of more MSC with a cell ratio of 1:1 (Fig. 6). Together, these data demonstrated that FK228or foretinib/FK228-treated MSC undergo morphological changes which was associated with alterations of the microenvironment by enhanced expression of structural proteins such as laminin and fibronectin. Moreover, MSC provide a certain protection for the tumor cells against cytotoxic effects of these chemotherapeutics.

To further substantiate these effects of the tumor microenvironment in altering the chemoreactivity of SCCOHT- 1 cells during tumor development, explant cultures were performed from two control tumors and three foretinib/FK228-treated mouse tumors and the derived cells were exposed in vitro to foretinib and FK228 alone or in combination. Thus, the sensitivity to foretinib alone was increased in two of the three treated tumors. In contrast, incubation of explant cells from all three previously treated tumors with $20 \mathrm{nM}$ FK228, $100 \mathrm{nM}$ FK228, or corresponding combinations with $0.5 \mu \mathrm{M}$ foretinib was always associated with a significantly elevated chemoresistance by $\sim 100 \%$ compared to explant cells from previously untreated mouse tumors (Fig. 7).

\section{Discussion}

To date, little knowledge is available on a successful therapy of rare tumors such as SCCOHT which is very unsatisfactory for the respective patients. Previous research has demonstrated some favorable results with epothilone B and higher calcium concentrations (29) as well as with foretinib as a multi-kinase inhibitor of c-Met and VEGF-Rs $(28,33)$.

A more promising approach by in vitro testing of various chemotherapeutic compounds alone and in combination revealed an efficient tumor cell killing of $>95 \%$ in SCCOHT-1 and BIN-67 cells following treatment with a combination of foretinib and FK228. Both compounds are part of clinical studies, respectively, whereby a combination of these drugs displays multiple effects. Foretinib inhibits c-Met signaling in SCCOHT-1 cells (28) whilst overexpression of c-Met and a paralleled hyperactivation in ovarian cancers correlates with poor prognosis by triggering tumor growth, metastasis and angiogenesis (34). In addition, FK228 predominantly targets tumor cells by interacting with the binding pocket of Zn-dependent histone deacetylase to block this enzyme activity and accordingly heterochromatin formation. In vivo treatment with foretinib/FK228 reduced angiogenesis and cell growth of SCCOHT-1 tumor xenografts by diminished detection of capillaries and Ki-67 positive cells which was also substantiated by down-modulation of the proliferation-associated cyclin D1 and the mVEGF-R2 involved in neo-vascularization. Inhibition of VEGF-R2 signaling by foretinib has been reported (33) and constitutive VEGF expression by SCCOHT-1-induced tumor xenografts paralleled by a down-modulation of the murine VEGF-R2 in foretinib/FK228-treated mice also indicated 
selective signaling blockage of cells within the tumor microenvironment rather than the tumor cells themselves.

Unfortunately however, little if any synergistic effects were observed with the tumor cell targeting compound FK228 in vivo, which left the combination of foretinib/FK228 below expectations by demonstrating much less effective tumor mass reduction as compared to previous studies with the c-Met inhibitor alone and by the simultaneous detection of lung metastases. In fact, the combination of foretinib and FK228 with an $\sim 6$-fold reduction in tumor mass was less efficient compared to foretinib alone in previous studies which displayed a $>10$-fold reduction of SCCOHT-1-induced tumor xenografts (28) suggesting certain resistance and/or some protective mechanisms induced during in vivo application.

Supportive evidence to follow this hypothesis was presented by the altered histopathology of foretinib/FK228-treated tumors with elevated expression of elastin van Gieson-positive structures in the tumor stroma. Moreover, analysis of the tumor tissue revealed enhanced expression of structural and connective tissue protein products such as laminin, elastin, and fibronectin. Whereas the majority of these extracellular matrix proteins and predominantly fibronectin is thought to be produced by MSC and stromal fibroblasts in the tumor microenvironment, analysis of the mouse tumor tissue also confirmed the expression of MSC-like markers including CD73 and CD90 which suggests an important role of MSC during foretinib/FK228-mediated SCCOHT-1 tumor cell protection. Indeed, potential protection of SCCOHT-1 cells was substantiated in vitro by MSC-induced expression of laminin and fibronectin after incubation with foretinib/FK228. In this context, previous research has demonstrated a protective role of MSC for cervical tumor cells (35). Interaction of MSC with ovarian cancer cells also contributed to increased metastatic ability (36). More importantly, co-cultures of MSC with SCCOHT-1 ${ }^{\mathrm{GFP}}$ cells revealed a significantly elevated resistance of the tumor cells against the cytotoxic action of FK228 alone or a combination of foretinib/FK228 when compared to a SCCOHT- ${ }^{\text {GFP }}$ mono-culture which further confirmed tumor-protective mechanisms of MSC. In addition, this MSC-mediated protection of SCCOHT- ${ }^{\text {GFP }}$ cells was also observed in co-cultures of MSC populations with the tumor cells, whereby increasing protective effects correlated with a corresponding elevated cell ratio of MSC. Finally, increased drug resistance was detectable in previously foretinib/FK228treated compared to untreated SCCOHT-1 explant tumor xenografts after repeated exposure to FK228 alone or a combination of foretinib/FK228.

Summary and outlook. Taken together, these findings demonstrated a tumor-protective role of MSC in SCCOHT tumors which would be in agreement with the conceptually natural functionality of MSC to generally support tissue repair and regeneration (37).

In contrast to very promising data of substantial tumor cell killing in SCCOHT tumor cell mono-culture assays in vitro, a markedly reduced effect was achieved by the chemotherapeutics in a multi-cell population microenvironment in vitro and in vivo. These discrepancies are linked to tumor cell protection by concomitant activation of particularly MSC within the tumor stroma. Consequently, a more effective therapeutic approach necessitates the application of an increased drug dosage in vivo to overcome the MSC-mediated protection of tumor cells. However, this also includes the risk of simultaneously increased side effects in treated patients. Therefore, drug-mediated alterations of tumor microenvironment-associated aberrant MSC with subsequent tumor cell protection may represent a more general phenomenon which exposes the tumor stroma as additional target for more focused chemotherapeutic effectiveness.

\section{Acknowledgements}

We thank Dr Petar Jelinic for providing initial substances. Yuanyuan Yang is supported by a postdoctoral fellowship from the DAAD and CSC. This study was supported by a grant from the Erich und Gertrud Roggenbuck-Stiftung for Cancer Research to Ralf Hass.

\section{References}

1. Dickersin GR, Kline IW and Scully RE: Small cell carcinoma of the ovary with hypercalcemia: A report of eleven cases. Cancer 49: 188-197, 1982.

2. Ulbright TM, Roth LM, Stehman FB, Talerman A and Senekjian EK: Poorly differentiated (small cell) carcinoma of the ovary in young women: Evidence supporting a germ cell origin. Hum Pathol 18: 175-184, 1987.

3. McCluggage WG, Oliva E, Connolly LE, McBride HA and Young RH: An immunohistochemical analysis of ovarian small cell carcinoma of hypercalcemic type. Int J Gynecol Pathol 23: 330-336, 2004.

4. Jelinic P, Mueller JJ, Olvera N, Dao F, Scott SN, Shah R, Gao J, Schultz N, Gonen M, Soslow RA, et al: Recurrent SMARCA4 mutations in small cell carcinoma of the ovary. Nat Genet 46: 424-426, 2014.

5. Witkowski L, Carrot-Zhang J, Albrecht S, Fahiminiya S, Hamel N, Tomiak E, Grynspan D, Saloustros E, Nadaf J, Rivera B, et al: Germline and somatic SMARCA4 mutations characterize small cell carcinoma of the ovary, hypercalcemic type. Nat Genet 46: 438-443, 2014.

6. Ramos P, Karnezis AN, Craig DW, Sekulic A, Russell ML, Hendricks WP, Corneveaux JJ, Barrett MT, Shumansky K, Yang Y, et al: Small cell carcinoma of the ovary, hypercalcemic type, displays frequent inactivating germline and somatic mutations in SMARCA4. Nat Genet 46: 427-429, 2014.

7. Karnezis AN, Wang Y, Ramos P, Hendricks WP, Oliva E, D'Angelo E, Prat J, Nucci MR, Nielsen TO, Chow C, et al: Dual loss of the SWI/SNF complex ATPases SMARCA4/BRG1 and SMARCA2/BRM is highly sensitive and specific for small cell carcinoma of the ovary, hypercalcaemic type. J Pathol 238: 389-400, 2016.

8. Kadoch C, Hargreaves DC, Hodges C, Elias L, Ho L, Ranish J and Crabtree GR: Proteomic and bioinformatic analysis of mammalian SWI/SNF complexes identifies extensive roles in human malignancy. Nat Genet 45: 592-601, 2013.

9. Foulkes WD, Clarke BA, Hasselblatt M, Majewski J, Albrecht S and McCluggage WG: No small surprise - small cell carcinoma of the ovary, hypercalcaemic type, is a malignant rhabdoid tumour. J Pathol 233: 209-214, 2014.

10. Witkowski L, Goudie C, Foulkes WD and McCluggage WG: Small-cell carcinoma of the ovary of hypercalcemic type (malignant rhabdoid tumor of the ovary): A review with recent developments on pathogenesis. Surg Pathol Clin 9: 215-226, 2016.

11. Johann PD, Erkek S, Zapatka M, Kerl K, Buchhalter I, Hovestadt V, Jones DT, Sturm D, Hermann C, Segura Wang M, et al: Atypical teratoid/rhabdoid tumors are comprised of three epigenetic subgroups with distinct enhancer landscapes. Cancer Cell 29: 379-393, 2016.

12. Witkowski L, Goudie C, Ramos P, Boshari T, Brunet JS, Karnezis AN,Longy M,Knost JA, Saloustros E, McCluggage WG, et al: The influence of clinical and genetic factors on patient outcome in small cell carcinoma of the ovary, hypercalcemic type. Gynecol Oncol 141: 454-460, 2016. 
13. Otte A, Göhring G, Steinemann D, Schlegelberger B, Groos S Länger F, Kreipe HH, Schambach A, Neumann T, Hillemanns P, et al: A tumor-derived population (SCCOHT-1) as cellular model for a small cell ovarian carcinoma of the hypercalcemic type. Int J Oncol 41: 765-775, 2012.

14. Gamwell LF, Gambaro K, Merziotis M, Crane C, Arcand SL, Bourada V, Davis C, Squire JA, Huntsman DG, Tonin PN, et al: Small cell ovarian carcinoma: Genomic stability and responsiveness to therapeutics. Orphanet J Rare Dis 8: 33, 2013.

15. Pittenger MF, Mackay AM, Beck SC, Jaiswal RK, Douglas R, Mosca JD, Moorman MA, Simonetti DW, Craig S and Marshak DR: Multilineage potential of adult human mesenchymal stem cells. Science 284: 143-147, 1999.

16. Caplan AI: Why are MSCs therapeutic? New data: New insight. J Pathol 217: 318-324, 2009.

17. Hass R, Kasper C, Böhm S and Jacobs R: Different populations and sources of human mesenchymal stem cells (MSC) A comparison of adult and neonatal tissue-derived MSC. Cell Commun Signal 9: 12, 2011.

18. Bianco P: 'Mesenchymal' stem cells. Annu Rev Cell Dev Biol 30: 677-704, 2014

19. Friedl $P$ and Alexander S: Cancer invasion and the microenvironment: Plasticity and reciprocity. Cell 147: 992-1009, 2011

20. Ungefroren H, Sebens S, Seidl D, Lehnert H and Hass R: Interaction of tumor cells with the microenvironment. Cell Commun Signal 9: 18, 2011.

21. Hass R and Otte A: Mesenchymal stem cells as all-round supporters in a normal and neoplastic microenvironment. Cell Commun Signal 10: 26, 2012.

22. Karnoub AE, Dash AB, Vo AP, Sullivan A, Brooks MW, Bell GW, Richardson AL, Polyak K, Tubo R and Weinberg RA: Mesenchymal stem cells within tumour stroma promote breast cancer metastasis. Nature 449: 557-563, 2007.

23. Mandel K, Yang Y, Schambach A, Glage S, Otte A and Hass R: Mesenchymal stem cells directly interact with breast cancer cells and promote tumor cell growth in vitro and in vivo. Stem Cells Dev 22: 3114-3127, 2013.

24. Yang Y, Otte A and Hass R: Human mesenchymal stroma/stem cells exchange membrane proteins and alter functionality during interaction with different tumor cell lines. Stem Cells Dev 24 $1205-1222,2015$

25. Yang Y, Bucan V, Baehre H, von der Ohe J, Otte A and Hass R: Acquisition of new tumor cell properties by MSC-derived exosomes. Int J Oncol 47: 244-252, 2015.

26. Upchurch KS, Parker LM, Scully RE and Krane SM: Differential cyclic AMP responses to calcitonin among human ovarian carcinoma cell lines: a calcitonin-responsive line derived from a rare tumor type. J Bone Miner Res 1: 299-304, 1986.
27. Yang Y, Melzer C, Bucan V, von der Ohe J, Otte A and Hass R: Conditioned umbilical cord tissue provides a natural threedimensional storage compartment as in vitro stem cell niche for human mesenchymal stroma/stem cells. Stem Cell Res Ther 7: $28,2016$.

28. Otte A, Rauprich F, von der Ohe J, Yang Y, Kommoss F, Feuerhake F, Hillemanns P and Hass R: c-Met inhibitors attenuate tumor growth of small cell hypercalcemic ovarian carcinoma (SCCOHT) populations. Oncotarget 6: 31640-31658, 2015.

29. Otte A, Rauprich F, Hillemanns P, Park-Simon TW, von der Ohe J and Hass R: In vitro and in vivo therapeutic approach for a small cell carcinoma of the ovary hypercalcaemic type using a SCCOHT-1 cellular model. Orphanet J Rare Dis 9: 126, 2014

30. Tsikitis M, Zhang Z, Edelman W, Zagzag D and Kalpana GV: Genetic ablation of Cyclin D1 abrogates genesis of rhabdoid tumors resulting from Inil loss. Proc Natl Acad Sci USA 102: 12129-12134, 2005.

31. Mazaud Guittot S, Vérot A, Odet F, Chauvin MA and le Magueresse-Battistoni B: A comprehensive survey of the laminins and collagens type IV expressed in mouse Leydig cells and their regulation by LH/hCG. Reproduction 135: 479-488, 2008.

32. Lu F, Ma FF, Zhang W, Li Y, Wei FY and Zhou L: Qualitative research of alternatively splice variants of fibronectin in different development stage of mice heart. J Thorac Dis 7: 2307-2312, 2015.

33. Zillhardt M, Park SM, Romero IL, Sawada K, Montag A, Krausz T, Yamada SD, Peter ME and Lengyel E: Foretinib (GSK1363089), an orally available multikinase inhibitor of c-Met and VEGFR-2, blocks proliferation, induces anoikis, and impairs ovarian cancer metastasis. Clin Cancer Res 17: 4042-4051, 2011.

34. Parr C and Jiang WG: Expression of hepatocyte growth factor/ scatter factor, its activator, inhibitors and the c-Met receptor in human cancer cells. Int J Oncol 19: 857-863, 2001.

35. Montesinos JJ, Mora-García ML, Mayani H, Flores-Figueroa E, García-Rocha R, Fajardo-Orduña GR, Castro-Manrreza ME, Weiss-Steider B and Monroy-García A: In vitro evidence of the presence of mesenchymal stromal cells in cervical cancer and their role in protecting cancer cells from cytotoxic T cell activity. Stem Cells Dev 22: 2508-2519, 2013.

36. Lis R, Touboul C, Halabi NM, Madduri AS, Querleu D, Mezey J, Malek JA, Suhre K and Rafii A: Mesenchymal cell interaction with ovarian cancer cells induces a background dependent prometastatic transcriptomic profile. J Transl Med 12: 59, 2014.

37. Melzer C, Yang Y and Hass R: Interaction of MSC with tumor cells. Cell Commun Signal 14: 20, 2016. 